\title{
Collecting and banking human milk: To heat or not to heat?
}

\author{
BENGT BJÖRKSTÉN, LARS G BURMAN， PETER DE CHÂTEAU， BO FREDRIKZON, \\ LEIF GOTHEFORS, OLLE HERNELL
}

\section{Summary and conclusions}

Data on human breast milk and its handling when fed to babies who cannot be breast-fed were reviewed to determine whether the method of processing and storage affected the properties of the milk. Breast milk is normally contaminated by potential pathogens, which seem to produce no ill effects, but it also contains antimicrobial properties which protect against infection. The evidence suggests that pasteurisation not only eliminates pathogenic bacteria but also damages bacteriostatic mechanisms, so making the milk more susceptible to later contamination. Pasteurisation also affects the nutritional properties of milk. Freezing has little effect on milk proteins, while a study on the effect of refrigeration showed that there was little bacterial growth at temperatures below $8^{\circ} \mathrm{C}$. Several years' experience of feeding donated raw milk to newborn infants has confirmed that it produces no ill effects.

These findings suggest that pasteurisation of donated breast milk is unnecessary, and it is not recommended, while the decision whether or not to freeze the milk may be made on practical grounds. Raw breast milk can be safely stored at $4-6^{\circ} \mathrm{C}$ for 72 hours.

Department of Paediatrics, University Hospital, S-901 85 Umeå, Sweden

BENGT BJÖRKSTÉN, MD, assistant professor (present address: Department of Biomedical Research, Pharmacia AB, S-751 04 Uppsala, Sweden) BO FREDRIKZON, MD, assistant professor

LEIF GOTHEFORS, $M D$, assistant professor

OLLE HERNELL, MD, assistant professor

Department of Clinical Bacteriokogy, University Hospital, S-901 85 Umeå, Sweden

LARS G BURMAN, MD, assistant professor

Department of Paediatrics, Karolinska Hospital, S-104 60 Stockholm, Sweden

PETER DE CHÂTEAU, MD, assistant professor

\section{Introduction}

With the renewed interest in feeding breast milk many hospitals have devised systems to ensure an adequate supply for infants who cannot be breast-fed, and some larger cities have milk banks. Donated milk is collected in several ways-by manual expression, collection from the opposite breast ("drip milk"), and manual or electric breast pumps-and either used fairly soon or stored in a refrigerator or freezer before use. It is usually boiled or pasteurised, but whether this is necessary or even seriously impairs nutritional value or host-defence mechanisms is a matter of controversy. ${ }^{1-4}$

We have therefore reviewed the effect of pasteurising, freezing, and refrigerating breast milk and studied bacterial growth during storage at different temperatures.

\section{CONTAMINATION OF HUMAN MILK}

\section{Bacteria}

Freshly collected human milk normally contains bacteria originating mainly from the skin and duct microflora of the nipples. Differences in methods of collecting milk may explain the great variations in bacterial contamination found in different studies (fig 1). Eidelmann and Szilagyi ${ }^{13}$ recently reported that $84 \%$ of milk specimens collected by an electric pump had flora similar to that present on the mother's nipple. Quantitative studies of the nipple flora before and after nursing showed median counts of staphylococci of 100 to 750 per $\mathrm{cm}^{2}$ on the nipples compared with about 2300 per $\mathrm{cm}^{2}$ on the forearm and $10^{6}$ per $\mathrm{cm}^{2}$ in the axilla, whereas Gram-negative bacteria (Escherichia coli, Serratia marcescens and Pseudomonas aeruginosa) were less common, occurring only in low numbers $\left(10-40\right.$ per $\left.\mathrm{cm}^{2}\right)$ on the nipples of $12 \%$ of the mothers. ${ }^{8}$ West $e t$ al ${ }^{9}$ reported that Staphylococcus was present in $24 \%$ of fresh milk samples from healthy mothers. No untoward effects on the recipient infants were observed. Thus contamination of milk by the indigenous nipple flora must be considered normal and acceptable, at least for milk given by a mother to her own baby. ${ }^{2}$ But should it be considered safe when the milk is given to the baby of another mother or to preterm and sick babies ?

Although doubts about feeding pyogenic staphylococci to babies have been expressed, ${ }^{2} 25-30 \%$ of preterm infants have Staph aureus in their gut within a few days after birth. These organisms are, however, seldom found in faeces at the age of 2-3 weeks and thus seem to be transient in the intestinal flora. ${ }^{14}$

Group B $\beta$-haemolytic streptococci may occur in human milk. ${ }^{15} 16$ Since streptococci colonise the oropharynx but rarely the skin, the 
route of contamination of breast milk with group A or B streptococci is probably from baby to nipples and milk rather than vice versa. ${ }^{9}$

Spread of tuberculosis via cows' milk is well established. Although little is known about possible transmission of tuberculosis by human milk, this may represent an obvious risk.

The presence of massive coliform counts in breast milk may indicate faecal contamination. But neither experience nor published data support the present doubts about giving human milk containing $E$ coli to infants. Most neonates are colonised very early by $E$ coli strains and many sick babies of low birth weight by klebsiella-enterobacter strains. Most of these strains are of non-maternal origin. ${ }^{17}$ The coliform flora of newborn infants is stable and a dominant strain will usually stay for three-five weeks despite continuous exposure to other serotypes in food or environmental sources. ${ }^{17}$ Thus the role of human milk in intestinal colonisation of infants remains unknown.

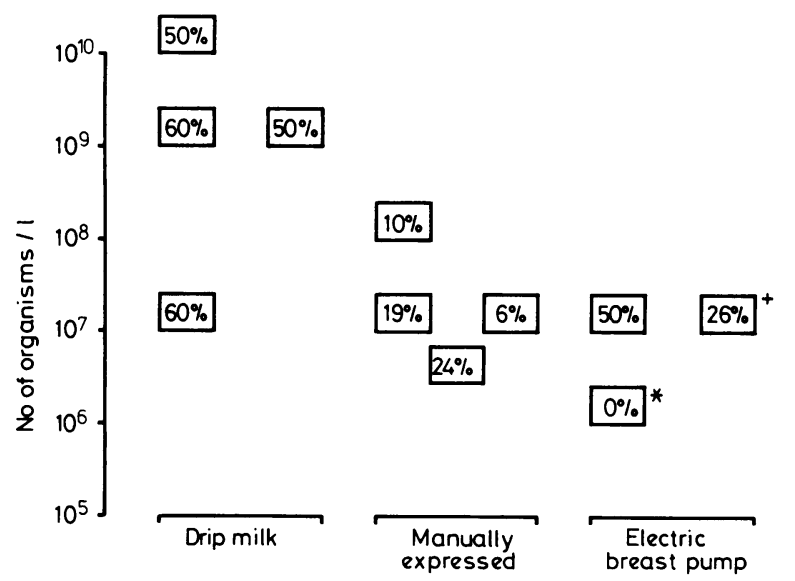

FIG 1 -Bacterial counts in milk specimens. Percentages represent proportions of samples with more than stated number of bacteria. Data compiled from cited references ${ }^{5-13} *$ data from GE Quinby, Louisiana State University Medical Centre (personal communication); $†$ our data).

\section{Enterotoxins and enzymes}

Another possible consequence of bacterial contamination of human milk is accumulation of enterotoxins (from Staph aureus and Bacillus cereus) and undesired enzymes-for example; lipases and amino-acid decarboxylases, some of the latter being capable of producing highly reactive amines. ${ }^{5}$ Protein synthesis in enteric organisms such as $E$ coli is, however, almost totally blocked below $8^{\circ} \mathrm{C}^{18}$ and Staph aureus is metabolically damaged by storage below $7^{\circ} \mathrm{C} .^{19}$ Also bacterial tRNA starts to function poorly very early during iron limitation-for example, as in human milk with intact lactoferrin-which arrests bacterial protein synthesis. ${ }^{20}$ Furthermore, other antibacterial systems in milk may contribute to the poor bacterial growth in breast milk at refrigerator temperatures (see below). Undesired bacterial products are therefore unlikely to be formed in milk during bacteriostasis.

Though substantial bacterial contamination $\left(10^{8} / 1\right)$ of human milk appears to have no ill effects on infants, contamination by hazardous pathogens may still constitute a risk. Besides rare anecdotal reports of infections suspected of being caused by contaminated human milk (usually processed) there are two reports of Salmonella kottbus outbreaks in neonatal intensive care units thought to be transmitted by human milk. ${ }^{21}{ }^{22}$ In both the source of the pathogen was probably the mother's mammary glands, but contaminated human milk was not proved to be the vehicle for transmission and alternative routes could not be excluded. The Centre for Disease Control, Atlanta, has no other reports on nosocomial infection caused by human milk since 1971 (J R Allen, personal communication). Although unprocessed donor milk has been liberally administered in Swedish and Finnish neonatal units for many years only one outbreak of infection related to such milk is known. This was caused by Salmonella typhimurium, and pasteurised milk was implicated, although alternative routes of transmission were also possible ( $\mathrm{P}$ Mäkelä, personal communication). Another nosocomial outbreak was caused by enteropathogenic $E$ coli $^{23}$ and again heat-processed milk was suspected of being the culprit. All these incidents may be related to the fact that human milk may lose its bacteriostatic capacity during heat treatment (see below).

\section{Viruses}

Herpes virus, cytomegalovirus, rubella, and hepatitis $B$ have been shown in human milk. ${ }^{24-26}$ There is no evidence that breast feeding contributes to infants becoming carriers of hepatitis B surface antigen, although this antigen is often found in the milk of carrier mothers. ${ }^{27}$ Since there are many alternative prenatal and postnatal routes of transmissions of viruses the role of human milk should not be overestimated, particularly in the light of the antiviral properties of fresh milk (see below). Nevertheless, any type of overt or suspected infection in a mother should disqualify her as a milk bank donor.

\section{ANTIMICROBIAL PROPERTIES OF MILK}

Human milk contains several antimicrobial systems. ${ }^{28}$ Secretory IgA predominates, with antibody activity directed towards several bacteria and viruses. Human milk is also rich in lactoferrin, which traps iron and thereby prevents the growth of iron-requiring bacteria. Folic acid and cyanocobalamin binding proteins may also have a similar bacteriostatic function. ${ }^{29}$ Bacteriostasis is also exerted by enzymes such as lactoperoxidase and lysozyme and by viable cells. Less is known about antiviral agents, but besides phagocytic cells and antiviral IgA antibodies human milk seems to contain a lipid-associated factor against enveloped viruse $\mathrm{s}^{30}$ and a non-lipid associated macromolecule with antiviral activity. ${ }^{31}$

The antimicrobial effects of most of these components have so far been shown only in vitro and it is unclear to what extent they operate in the gastrointestinal tract of the breastfed infant. Nevertheless, several studies have shown that gastroenteritis is less common and less severe in breast-fed than in formula-fed infants. ${ }^{32}$ Furthermore, in developing countries infants may often be colonised by pathogens such as Vibrio cholerae, Shigella, Salmonella, and enteropathogenic $E$ coli without developing symptoms so long as they are breast-fed. ${ }^{32}{ }^{33}$ Other studies have indicated a lower incidence of severe systemic infections in breast-fed infants. ${ }^{34}$ In a recent prospective and randomised study from India the incidence of major infections was reduced by giving fresh, untreated colostrum or raw mature human milk instead of formula milk to sick infants of low birth weight. ${ }^{35}$

\section{LIVE CELLS}

There is a theoretical risk of graft-versus-host reactions caused by live immunocompetent cells in human. milk, but none have been reported. In Scandinavia many years' experience of feeding unprocessed human milk or colostrum has shown no immunological hazards from giving live'cells to even preterm infants unrelated to the donors.

\section{DECONTAMINATION OF MILK BY HEAT TREATMENT}

Although there is little evidence that bacterial contamination of human milk poses a hazard to the infant, standard processing in most institutions includes' heat-treatment. Heating milk to $.105^{\circ} \mathrm{C}$ decontaminates milk even if it is heavily infected with $E$ coli and Staph aureus. ${ }^{1}$ When pasteurisation, which, was originally designed to kill Mycobacterium tuberculosis bovis in bovine milk, was adopted in human milk banks ${ }^{36}$ the effects on other micro-organisms were little considered. Pasteurisation at $62.5^{\circ} \mathrm{C}$ for 5 minutes reduces the viable bacterial counts by $90 \%$ or more. Holder pasteurisation $\left(62.5^{\circ} \mathrm{C}\right.$, 30 minutes) does not guarantee complete decontamination of all milk samples although it seems to eliminate pathogenic bacteria. ${ }^{56}$ The number and type of micro-organism as well as the exact temperature and time of heating seem to influence the efficiency of decontamination. The holder process recommended by several authors seems to be a compromise between "acceptable" decontamination and preservation of the bacteriostatic properties in milk.

\section{Antimicrobial factors}

Since most proteins will denaturate when exposed to heat, heattreatment should have an adverse effect on the milk. Available data are confined mainly to the effects on milk components with antimicrobial properties. Table I shows that holder pasteurisation reduced to some extent the activity of most antimicrobial constituents. The stability of lysozyme, which was among the constituents least affected by pasteurisation, is probably influenced by the $\mathrm{pH}$ of the individual milks. ${ }^{29}$ The viable cells in milk are very sensitive to heat 
and even mild heat-treatment will lead to an almost complete destruction.

Generally, increased temperature denatures proteins more rapidly, while freezing (that will not cause decontamination) is less harmful (table I). The varying results in different studies may be explained at least partly by differences in methods. As illustrated in fig 2 , which shows loss of activity of IgA, lactoferrin, and lysozyme with increasing temperature, an exact and reproducible method is critical. At $62 \cdot 5^{\circ} \mathrm{C}$ (the most commonly used temperature for holder pasteurisation) lactoferrin was rapidly inactivated and a small change in the exact temperature or time of pasteurisation had a pronounced effect. IgA and lysozyme did not lose their activity at $62.5^{\circ} \mathrm{C}$, but this was the upper limit at which full activity was retained. A small increase in temperature had profound effects, that is, at $65^{\circ} \mathrm{C}$ the loss of lysozyme activity was $30 \%$ and that of IgA $50^{\circ}{ }_{0}$. Other factors such as time for reaching exact temperature, time for cooling, volumes processed, and total milk protein concentrations will also influence the exact results.

TABLE I-Percentage decreases in constituents of breast milk samples treated by heating and freezing and thawing as compared with values in raw milk

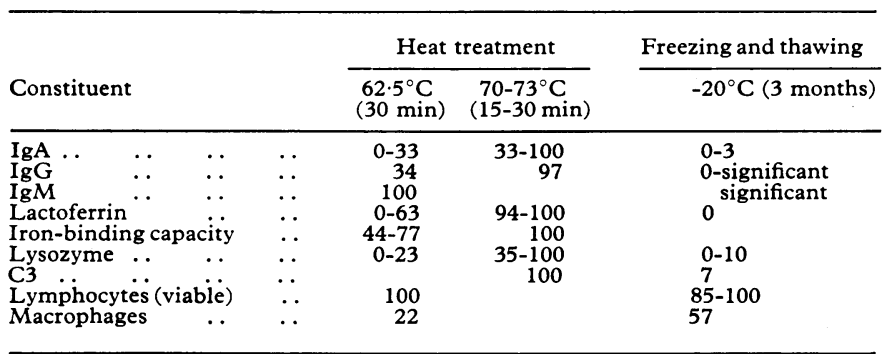

*Data from references $6,8,29,37,38$, and 39.

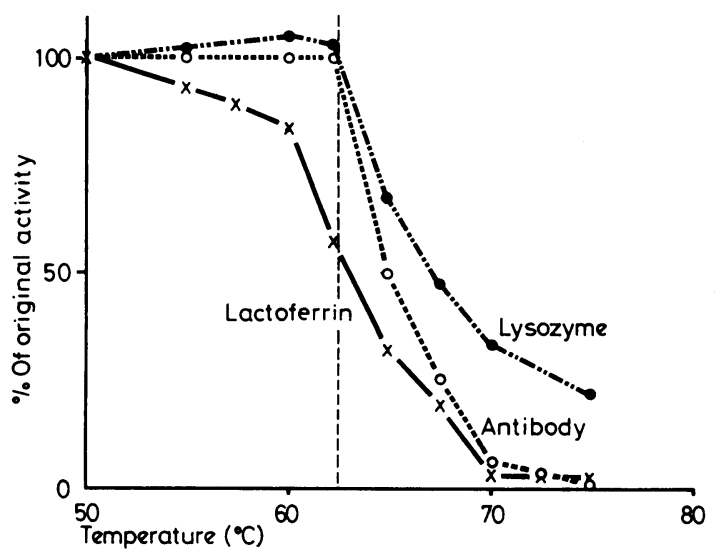

FIG 2-Sensitivity to heat of $E$ coli 026 B 6 antibody, lysozyme, and lactoferrin. (From Eyres et al. ${ }^{38}$ )

Since several studies have shown that bacteria added to pasteurised milk grow more rapidly than those added to raw human milk ${ }^{69} 3840$ it is probably relevant that pasteurisation is often not complete. Microorganisms that escape pasteurisation or contaminate later might grow faster when the bacteriostatic systems of the milk have been damaged and human milk will be more vulnerable to contamination later. Thus, heat-processing of human milk might increase the risk of nursery outbreaks caused by undesired enteric pathogens.

\section{Nutritional factors}

The effect of heat-treatment on nutritional factors in human milk has been little studied. Some milk proteins will denaturate when exposed to heat. Like iron, cyanocobalamin and folic acid, two other principal nutritional requirements for blood cells, are specifically bound to proteins in human milk, and these will be at least partly inactivated by holder pasteurisation. ${ }^{29}$ Whether this protein binding is important for absorbing iron, folic acid, and vitamin $B_{12}$ from the milk, either by preventing their uptake from intestinal bacteria or by other mechanisms, is not known.

Pasteurisation of bovine milk does not destroy the caseins, $\alpha$ lactalbumin, lactose, or most vitamins, except for vitamin C, where a $50 \%$ loss has been recognised. ${ }^{41}$

Although pasteurisation will denaturate individual milk proteins, neither absorption nor retention of nitrogen is reduced in infants born at term when human milk is pasteurised. ${ }^{42}$ In a recent comprehensive study using serial metabolic balance techniques in preterm infants Williamson $e t a^{43}$ compared the resorption of nitrogen, fat, sodium, calcium, and phosphorus from raw and heat-treated human milk. The heat-treated milk was either exposed to $63^{\circ} \mathrm{C}$ for 30 minutes or boiled. There was no significant difference between the three milks in the absorption of nitrogen, sodium, phosphorus, or calcium, but there was a pronounced effect on the absorption of lipids. The highest fat

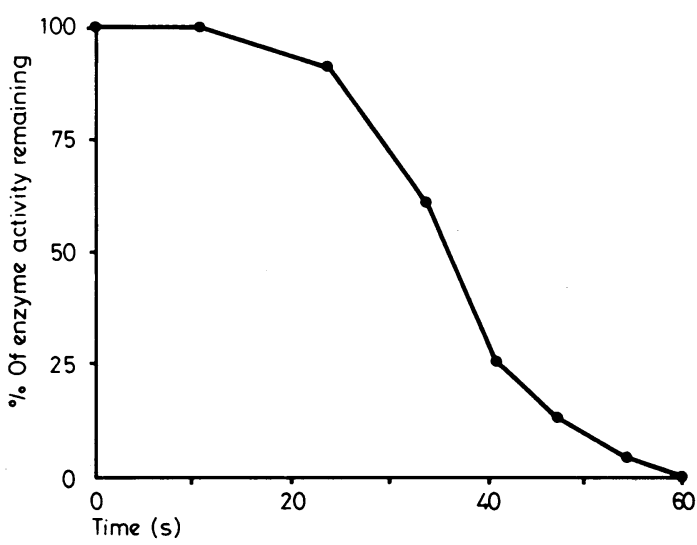

FIG 3-Inactivation of human milk bile salt-stimulated lipase at $62.5^{\circ} \mathrm{C}$. Raw human milk $(1 \mathrm{ml})$ incubated in water bath. At times indicated samples withdrawn and bile saltstimulated lipase activity determined as described. ${ }^{47}$

absorption occurred from raw milk in all infants. The average absorption was $74 \%$ from raw milk, $54 \%$ from pasteurised milk, and $46 \%$ from boiled milk. Thus, pasteurisation decreased the absorption of lipids by about a third, corresponding to about $16 \%$ of the consumed energy. The infants also gained weight most rapidly when fed raw milk.

There are two reasons why heat-treatment of human milk would reduce the absorption of lipids more than that of other major nutrients. Neonates, especially preterm infants, have a low endogenous capacity to hydrolyse and absorb dietary lipids. ${ }^{44}{ }^{45} \mathrm{Human}$ milk contains a heatlabile lipase that when activated by bile salts in the duodenum contributes to the hydrolysis of milk lipids-that is, its triglycerides and vitamin A-esters. ${ }^{45}{ }^{46}$ In the study of Williamson et al ${ }^{43}$ the difference in fat absorption between raw and pasteurised milk was highly significant while that between pasteurised and boiled milk was not. This is consistent with the finding that milk lipase completely lost its activity within the first minute of pasteurisation at $62 \cdot 5^{\circ} \mathrm{C}$ (fig 3 ).

Decontamination of human milk is clearly a delicate problem. Not only micro-organisms but also viable cells and many proteins in milk are heat labile. Some of the proteins, such as immunoglobulins, vitamins, and metal-binding proteins and enzymes, have known (and unknown?) biological activities that affect the antimicrobial and nutritional value of the milk. Even mild heat treatment will inactivate some of these factors. We therefore consider that holder pasteurisation should not be recommended as a safe and reproducible routine method for decontamination.

\section{STORAGE OF HUMAN MILK}

\section{Freezing}

Freezing neither decreases the content of live bacteria nor denaturates milk proteins, although the cells present in milk are killed (table I). Thus the decision whether or not to freeze breast milk for storage or transportation seems to be mainly a practical question. 


\section{Refrigeration}

In all milk banking systems milk is stored for some periods in a refrigerator. Since information on bacterial growth under such conditions is limited we conducted some studies.

A pool of milk samples obtained from eight donors was experimentally inoculated with 156 bacterial isolates ( $E$ coli 85 strains, Klebsiella pneumoniae 15, Enterobacter sp 10, Citrobacter sp 5, Serratia marcescens 5, Pseudomonas aeruginosa 5, Staph aureus 15, Staph epidermidis 10, and 6 Gram-negative non-fermenting psychrotrophic isolates from sewage). All inoculates were $10^{7} / \mathrm{ml}$. No bacteria grew during incubation at $4^{\circ} \mathrm{C}$ for 10 days. At 6 to $8^{\circ} \mathrm{C}$ there was no growth of psychrotrophs in 30 hours, but at 48 hours three isolates had multiplied slightly (threefold to fourfold) and four isolates showed a more than a tenfold increase after seven days. To ascertain that milk from certain individuals was not less bacteriostatic than that of others, each of 25 individual milks was inoculated with 25 Gram-negative clinical isolates. There was no growth when the samples were incubated for seven days at $4^{\circ}, 6^{\circ}$, or $8^{\circ} \mathrm{C}$. We also compared bacterial growth in raw and in heated breast milk (table II). Staphylococci did not multiply in raw milk even at $22^{\circ} \mathrm{C}$, whereas the Gram-negative bacteria grew at this temperature in both raw and heated milk.

TABLE II-Growth of bacteria incubated at various temperatures for 30 hours in raw breast milk and breast milk $(500 \mathrm{ml})$ heated to $80^{\circ} \mathrm{C}$ and allowed to cool in air

\begin{tabular}{|c|c|c|c|c|}
\hline$\frac{\text { Bacteria }}{\text { Type }}$ & No & Milk & $\begin{array}{c}\text { Incubation } \\
\text { temperature }\left({ }^{\circ} \mathrm{C}\right)\end{array}$ & Growth \\
\hline $\begin{array}{l}\text { Staphylococci } \\
\text { Staphylococci } \\
\text { Staphylococci } \\
\text { Staphylococci }\end{array}$ & $\begin{array}{l}10^{*} \\
10^{*} \\
10^{*} \\
10^{*}\end{array}$ & $\begin{array}{l}\text { Raw } \\
\text { Heated } \\
\text { Raw } \\
\text { Heated }\end{array}$ & $\begin{array}{r}6-8 \\
6-8 \\
22 \\
22\end{array}$ & $\begin{array}{l}\text { None } \\
\text { None } \\
\text { None } \\
\text { None }\end{array}$ \\
\hline $\begin{array}{l}\text { Gram-negative } \\
\text { Gram-negative } \\
\text { Gram-negative } \\
\text { Gram-negative }\end{array}$ & $\begin{array}{l}20 \dagger \\
20 \dagger \\
20 \dagger \\
20 \dagger\end{array}$ & $\begin{array}{l}\text { Raw } \\
\text { Heated } \\
\text { Raw } \\
\text { Heated }\end{array}$ & $\begin{array}{r}6-8 \\
6-8 \\
22 \\
22\end{array}$ & $\begin{array}{c}\text { None } \\
\text { None } \\
\text { Tenfold increase } \\
\text { Tenfold increase }\end{array}$ \\
\hline
\end{tabular}

* $S$ aureus, five strains; $S$ epidermidis, five strains.

$\dagger E$ coli, 14 strains; psychrotrophic Gram-negative organisms, six strains.

At $4^{\circ} \mathrm{C}$ therefore no bacterial growth was seen, while at $6-8^{\circ} \mathrm{C}$ occasional free-living Gram-negative organisms adapted to low temperatures (but none of the clinical isolates) multiplied very slowly. Incubation temperature and type of organism, rather than the properties of individual milks, seemed to determine the thresholds for bacterial growth. We therefore conclude that breast milk contaminated with various bacteria can be safely stored at $4^{\circ} \mathrm{C}$ and at $6^{\circ} \mathrm{C}$ for at least 72 hours. Even longer storage periods at $6-8^{\circ} \mathrm{C}$ would constitute a minimal risk for growth of potential pathogens.

\section{Experience in Umeå}

For several years we have given raw milk collected in the hospital to newborn infants. For the past year we have also routinely used frozen milk delivered by lactating women outside the hospital. Prospective milk donors are questioned about their general health, exposure to tuberculosis, medication, occupational exposure to chemicals, presence of diarrhoea or symptoms of other current infections, and alcohol and smoking habits and a chest radiograph is taken. Since hepatitis B is uncommon in our region laboratory screening for this virus has not been thought necessary.

The donors are carefully instructed about personal hygiene and milk collection and storage techniques. Most of our home donors prefer to use the Egnell electric breast pump. Collection vessels and other accessories are supplied by the milk bank and are disinfected in dish washers or by boiling before use. The milk collected at each meal over 24 hours is stored in a refrigerator in separate vessels. The portions are then pooled and frozen once daily. The frozen milk is collected once a week or at least within one month. The first three deliveries from each mother are subject to bacteriological control and if the viable counts are $10^{8} / 1$ or less the milk is used without heat treatment. No further systematic bacteriological control of that mother's milk is performed.

Human milk donated in the hospital is collected in auto- $D$ claved shells or bottles and is not routinely checked for bacterial contamination. Our intrahospital milk collection system is, however, bacteriologically monitored for one day every three months, when all milk samples delivered that day as well as pumps and other equipment are subject to bacteriological $\stackrel{\vec{\sim}}{\rightarrow}$ control.

Thawed milk may be stored for up to 72 hours at $4^{\circ} \mathrm{C}$ before use, although it is rarely stored for more than 24 hours. We try to $\frac{\text { क }}{\frac{7}{\sigma}}$ reserve the small quantities of colostrum and very early milk $\stackrel{\mathbb{Q}}{\varrho}$ collected in the maternity wards for the newborn infants, particularly those who are preterm, whereas milk from com- 2 munity donors is given mainly to older infants. We have not experienced any untoward effects of unpasteurised milk col- $\overrightarrow{\vec{\omega}}$ lected and administered as described.

\section{Conclusions and recommendations}

We consider that raw human milk is better than heat-processed milk for infant nutrition and defence against infection. We are not aware of any hazards caused by administering milk $\mathrm{F}$ naturally contaminated with potential pathogens, and bacterial 음 toxins and enzymes potentially capable of spoiling the milk are $\mathrm{N}$ unlikely to be produced so long as bacterial multiplication in the is milk is prevented. The holder pasteurisation of breast milk $\mathbb{D}$ recommended by most workers'needs to be done very accurately $\mathbb{D}$ to avoid denaturation of proteins while still yielding efficient $\frac{3}{0}$ decontamination, and most hospitals will have difficulties in controlling the process well enough under routine clinical $\vec{\bullet}$ conditions. Inadequate pasteurisation may not only damage the $\mathscr{O}$ presumed beneficial properties of breast milk but may also increase its susceptibility to subsequent bacterial contamination. Our own experience of giving raw milk to newborn infants confirms that pasteurisation is unnecessary.

These studies were supported by grants from the Swedish Medical $\stackrel{2}{\perp}$ Research Council (numbers 19X-05708, 16X-5217, and 19X-765), the $\overrightarrow{\vec{P}}$ Wennergrenska Samfundet, the Swedish Baby Food Industry Fund $\frac{9}{3}$ for Nutritional Research, the Swedish Nutrition Foundation, Action for the Crippled Child, Tore Nilssons Fund for Medical Research, and the J C Kempe Foundation.

\section{References}

1 Anonẏmous. Heating human milk. Br Med $\mathcal{F} 1977$;i : 1372.

2 Lucas A, Goddard P, Baum JD. Raw or pasteurised human milk ? Br Med $\mathcal{3}$ $1978 ; \mathrm{i}: 781$.

${ }^{3}$ Roy CC, Lescop J. Human milk banking. High rate of interest for a still 윽 uncertain credit balance. Am 7 Dis Child 1979;133:255-6.

4 Anonymous. Sterilisation of human milk. Lancet $1979 ; 1: 913$.

5 Lucas A, Roberts CD. Bacteriological quality control in human milk- $\frac{I}{C}$ banking. Br Med f 1979; :80-2.

${ }^{6}$ Gibbs JH, Fisher C, Bhattacharya S, Goddard P, Baum JD. Drip breast $N$ milk: its composition, collection and pasteurisation. Early Hum Dev న్
$1977 ; \mathrm{i}: 227-45$.

${ }^{7}$ Carrol L, Davies DP, Osman M, McNeish AS. Bacteriological criteria for feeding raw breast-milk to babies on neonatal units. Lancet $1979 ; \mathrm{ii}: 0$ $732-3$

8 Gothefors L. Studies of antimicrobial factors in human milk and bacterial $\stackrel{\mathscr{D}}{\mathscr{D}}$ colonisation of the newborn. Thesis. Umeå: Umeå University Medical ? Dissertations, 1975.

9 West PA, Hewitt JH, Murphy OM. The influence of methods of collection $\bar{O}$ and storage on the bacteriology of human milk: $\mathcal{F}$ Appl Bacteriol 1979; 46:269-77.

10 Williamson S, Hewitt JH, Finucane E, Gamsu HR. Organisation of bank of $\stackrel{\mathbb{Q}}{\varrho}$ raw and pasteurised human milk for neonatal intensive care. $\mathrm{Br} \mathrm{Med} \mathcal{F}$ ర $1978 ; \mathrm{i}: 393-6$.

11 Davidson DC, Poll RA, Roberts C. Bacteriological monitoring of un- 응 heated human milk. Arch Dis Child 1979;54:760-4.

${ }^{12}$ Liebhaber M, Lewiston NJ, Asquith MT, Sunshine P. Comparison of bacterial contamination with two methods of human milk collection. F Pediatr 1978;92:236-7.

13 Eidelman AI, Szilagyi G. Patterns of bacterial colonisation of human milk. Obstet Gynecol $1979 ; 53: 550-2$. 
14 Gothefors L, Davies PA. Feeding pre-term infants with raw and heatsterilised human milk: effects on faecal flora. In: Visser HKA, ed. Nutrition and metabolism of the fetus and infant. The Hague: Nijhoff Publishers, 1979.

${ }^{15}$ Kenny JF, Zedd AJ. Recurrent group B streptococcal disease in an infant associated with the ingestion of infected mother's milk. $\mathcal{F}$ Pediatr 1978; 91:158.

${ }^{16}$ Schreiner RL, Coates T. Possible breast milk transmission of group B streptococcal infection. $\mathcal{F}$ Pediatr. 1978;91:159.

17 Gothefors L, Carlsson B, Ahlstedt S, Hanson LA, Winberg J. Influence of maternal gut flora and colostral and cord serum antibodies on presence of Escherichia coli in faeces of the newborn infant. Acta Paediatr Scand $1976 ; 65: 225-32$.

18 Friedman H, Lu P, Rich A. Temperature control of initiation of protein synthesis in Escherichia coli. $f$ Mol Biol $1971 ; 61: 105-21$.

19 Patterson TE, Jackson H. Loss of viability and metabolic injury of Staphylococcus aureus resulting from storage at $1^{\circ}, 3^{\circ}, 5^{\circ}$ and $7^{\circ} \mathrm{C}$. I Appl Bacteriol 1979 ;46:173-7.

20 Griffiths E, Humphreys J. Alterations in tRNAs containing 2-Methylthio- $\mathrm{N}^{6}-\left(\triangle^{2}\right.$-isopentenyl)-adenosine during growth of enteropathogenic Escherichia coli in the presence of iron-binding proteins. Eur $\mathcal{F}$ Biochem 1978;82:503-13.

${ }^{21}$ Ryder RW, Crosby-Ritchie A, McDonough B, Hall III WC. Human milk contaminated with Salmonella kottbus. A cause of nosocomial illness in infants. $\mathcal{F} A M A 1977 ; 238: 1533-4$

22 Center for Disease Control: Salmonella kottbus meningitis associated with contaminated breast milk. Morbidity Mortality Weekly Rep 1971;20: 154.

23 Stiver HG, Albritton WL, Clark J, Friesen P, White FMM. Nosocomial colonisation and infection due to E.coli $0125: \mathrm{K} 70$ epidemiologically linked to expressed breast-milk feedings. Can $\mathcal{f}$ Public Health 1977;68: 479-82.

${ }^{24}$ Shiraki K, Yoshihara N, Kawana T, Yasui H, Sakurai M. Hepatitis B surface antigen and chronic hepatitis in infants born to asymptomatic carrier mothers. Am $\mathcal{F}$ Dis Child 1977;131:644-7.

${ }^{25}$ Kibrick S. Herpes simplex virus in breast milk. Pediatrics 1979;64:390-1.

${ }_{26}$ Welsh JK, Arsenakis M, Coelen RJ, May JT. Effect of antiviral lipids, heat and freezing on the activity of viruses in human milk. $\mathcal{F}$ Infect Dis 1979;140:322-8.

27 Boxall EH, Derso A, Flewett TH. Breast feeding in hepatitis B carrier mothers. In Proceedings International Symposium on Breast Feeding, Tel Aviv 1980. Excerpta Medica (in press).

28 Welsh JK, May JT. Anti-infective properties of breast milk. $\mathcal{F}$ Pediatr 1979;94:1-9.

${ }^{29}$ Ford JE, Law BA, Marshall VME, Reiter B. Influence of the heat treatment of human milk on some of its protective constituents. $\mathcal{F}$ Pediatr $1977 ; 90: 29-35$

${ }^{30}$ Welsh JK, Skurrie IJ, May JT. Use of Semliki forest virus to identify lipid-mediated antiviral activity and anti-alphavirus immunoglobulin $\mathrm{A}$ in human milk. Infect Immun 1978;19:395-401.
${ }^{31}$ Matthews THJ, Lawrence MK, Nair CDG, Tyrrell DAJ. Antivira activity in milk of possible clinical importance. Lancet 1976;ii:1387-9.

32 Larguia AM, Urman J, Stoliar OA et al. Fresh human colostrum for the prevention of $E$ coli diarrhoea-a clinical experience. Environ Child Health $1977 ; 23: 289$.

${ }^{33}$ Mata LJ, Urrutia JJ. Infections and infectious diseases in a malnourished population: a long-term prospective field study. In Food and Immunology. Stockholm: Swedish Nutrition Foundation, 1977: 42-57.

34 Winberg J, Wessner G. Does breast milk protect against septicaemia in the newborn? Lancet $1971 ; \mathrm{i}: 1091-4$

${ }^{35}$ Naraynan I, Prakesh K, Bala S, Verma RK, Gujral VV. The use of breast milk in the prevention of infection in the high risk newborn infant. Proceedings from "International Conference on infant nutrition and diarrhoea disease." Kuala Lumpur. 1979:130.

${ }^{36}$ Lloyd Jones C, Jennison RF, D'Souza SW. Bacterial contamination of expressed breast milk. Br Med f 1979 ;ii :1320-2.

37 Raptopoulou-Gigi M, Marwick K, McClelland DBL. Antimicrobial proteins in sterilised human milk. $\mathrm{Br} \mathrm{MedF} 1977$; :12-4.

${ }^{38}$ Eyres R, Elliott RB, Howie RN, Farmer K. Low-temperature pasteurisation of human milk. NZ MedF 1978;87:134-5.

${ }^{39}$ Liebhaber M, Lewiston NJ, Asquith MT, Olds-Arroyo L, Sunshine P. Alterations of lymphocytes and of antibody content of human milk after processing. F Pediatr 1977;91:897-900.

${ }^{40}$ Hernandez J, Lemons P, Lemons J, Todd J. Effect of storage processes on the bacterial growth-inhibiting activity of human breast milk. Pediatrics $1979 ; 63: 597-601$.

${ }^{41}$ Downey WK, Fox PF. Milk processing $-R$ and $D$ Focus and needs. In Downey WK ed. Food quality and nutrition. Barking: Applied Science Publications Ltd, 1979: 41-105.

42 Fomon SJ, Lora N, Thomas RN, May CD. Equivalence of pasteurised and fresh human milk in promoting nitrogen retention by normal fullterm infants. Pediatrics 1958;22:935-44.

43 Williamson S, Finucane E, Ellis H, Gamsu RH. Effect of heat treatment of human milk on absorption of nitrogen, fat, sodium, calcium and phosphorus by preterm infants. Arch Dis Child 1978;53 :555-63.

${ }^{44}$ Hamosh M. A review. Fat digestion in the newborn: role of lingual lipase and preduodenal digestion. Pediatr Res 1979;13:615-22.

45 Hernell O, Blackberg L, Fredrikzon B, Olivecrona T. The bile-saltstimulated lipase in human milk and lipid digestion in the neonata period. In: E Lebenthal, ed. Gastrointestinal development and infant nutrition. New York: Raven Press (in press).

46 Fredrikzon $B$, Hernell $O$, Bläckberg L, Olivecrona T. Bile salt-stimulated lipase in human milk: evidence of activity in vivo and of a role in the digestion of milk retinol esters. Pediatr Res 1978;12:1048-52.

47 Hernell O, Olivecrona T. Human milk lipases II. Bile salt-stimulated lipase. Biochim Biophys Acta 1974 ;369:234-44.

(Accepted 11 fuly 1980)
ONE HUNDRED YEARS AGO A local paper calls attention to a case in which Dr Hardwicke held an inquest at the St Pancras Coroner's Court concerning the death of Edward May, aged thirteen, of North Crescent Mews; Burton Crescent. It appears that the deceased was wheeling a costermonger's barrow along the Euston Road; when a horse and hansom cab accidentally knocked against some boards which were upon the barrow, and they struck the deceased in the stomach. Not much notice was taken of the accident at the time, and deceased went home; but, two days afterwards, as he was very ill, the mother sent for Mr L Franklyn, of Burton Crescent, and as the fee was not paid he refused to attend, upon which the mother, as her husband had gone to the market, borrowed the fee, three shillings, which she sent to $\mathrm{Mr}$ Franklyn, and upon his ( $\mathrm{Mr}$ Franklyn) attending, he found that the boy was dead. Mr Franklyn, in his evidence, stated that a little girl came to his house in an excited state, and stated that her brother was dying. He asked her if she had the fee, and on her telling him she had not, he, in consequence of having been sent for many times, and not been able to get his fee from different people that lived in the same mews, told her that directly she got the fee he would go. About a quarter of an hour afterwards, the little girl returned with the fee, three shillings, and paid him, upon which he went to see the deceased at once, and then found that he was dead. $\mathrm{He}$ had since made a post mortem examination, and found that death was due to a rupture of the spleen. The foreman of the jury said he thought Mr Franklyn would have been showing a feeling of humanity, had he gone to see the deceased without his miserable fee. The Coroner said he thought Mr Franklyn might have gone to see the deceased, but he would remind them (the jury) that a medical man was not bound to go: whenever he was called. The foreman of the jury asked whether arrangements could not be made so that in a case similar to the present, a medical man, when called by poor persons, could be paid by the Guardians or some other public body; for it was hard that a person should die because they could not obtain the paltry fee. The Coroner said in other great cities there were stations where a medical man could be seen at any time of the day or night. The jury returned a verdict of "Accidental Death." This report will be read with interest in connection with the system of immediate medical relief on application to police-stations, together with an organised system of public succour in emergencies, which has existed now in Paris for some few years, and which, from the reports of which we from time to time publish abstracts, appears to work well. It is about to be introduced in New York. It is true that, in this country, we have an extensive system of Poor-law medical relief which meets all but emergent cases; and we hope to see such a network of provident dispensaries established in our great towns as will make insurance against sickness the rule among our working classes; so that everyone will know where to send to a medical man who has been paid beforehand, by small subscriptions, in anticipation of emergencies. This great principle of insurance against sickness is that which needs to be instilled into the minds, and introduced into the habits of our working classes. It is to that end that the long continued activity of many medical men, and the persistent and admirable labours of Sir Charles Trevelyan, tend; but exceptions will always exist; and it is in view of these exceptions, which, in a city so populous as London, will probably never be very few, that incidents such as are disclosed by this inquest appear to support the proposition for a system of medical relief in emergency corresponding to that now working in Paris. (British Medical fournal, 1880.) 